\title{
Pengaruh Sudut Potong dan Kecepatan Putaran Spindel Terhadap Kekasaran Permukaan pada Proses Bubut Mild Steel ST 37
}

\author{
Yufrizal $\mathbf{A}^{1^{*}}$ Eko Indrawan ${ }^{1}$ Nofri Helmi ${ }^{1}$ Abdul Aziz ${ }^{1}$ dan Yoga Amanda Putra ${ }^{1}$ \\ ${ }^{1}$ Jurusan Teknik Mesin, Fakultas Teknik, Universitas Negeri Padang \\ ${ }^{*}$ Corresponding author, e-mail: ekoindrawan@ft.unp.ac.id
}

\begin{abstract}
Abstrak - Kualitas permukaan hasil pembubutan dapat dipengaruhi oleh beberapa faktor seperti menentukan kecepatan putaran spindel, menentukan kecepatan potong (cutting speed), sudut potong. Tujuan penelitian ini adalah untuk membandingkan tingkat kekasaran permukaan pada proses bubut Mild Steel ST 37. Setiap permukaan dari benda kerja yang telah mengalami proses permesinan akan mengalami tingkat kekasaran yang berbeda-beda. Penelitian ini merupakan penelitian eksperimen yang membandingkan tingkat kekasaran permukaan benda Mild Steel ST 37. Bahan yang dikerjakan dengan panjang $70 \mathrm{~mm}$, dan dibubut menjadi diameter $20 \mathrm{~mm}$ dengan menggunakan 3 macam sudut potong dan 3 macam kecepatan putaran spindel. Alat ukur uji kekasaran permukaan benda kerja yaitu surface tester mitutoyo SJ-201P. Hasil penelitian ini dapat disimpulkan bahwa kecepatan putaran spindel $740 \mathrm{rpm}$ dengan sudut potong $80^{\circ}$ menghasilkan permukaan yang lebih halus yaitu $\left(\sum R a_{p}\right)=5,76 \mu \mathrm{m}$ atau pada kelas kekasaran N9 sedangkan kecepatan putaran spindel $440 \mathrm{rpm}$ dengan sudut potong $80^{\circ}$ menghasilkan permukaan yang kasar $\left(\sum R a_{p}\right)=11,47 \mu$ dengan kelas kekasaran permukaan $N 10$.
\end{abstract}

Kata Kunci : Kecepatan Putaran Spindel, Sudut Potong, Kekasaran Permukaan

\begin{abstract}
The surface quality of turning can be influenced by several factors such as determining the spindle rotation speed, determining cutting speed (cutting speed), cut angle. the purpose of this study was to compare the level of surface roughness in the mild steel ST 37 on lathe process. Every surface of the workpiece that undergoes a machining process will experience varying degrees of roughness. This research is an experimental study that compares the level of surface roughness of material material Mild Steel ST 37. Material that is done with a length of $70 \mathrm{~mm}$, and turned into a diameter of $20 \mathrm{~mm}$ using $3 \mathrm{kinds}$ of cutting angles and 3 kinds of spindle rotation speed. Measuring the surface roughness of the workpiece, namely surface tester mitutoyo SJ-201P. The results of this study can be concluded that the spindle rotation speed of $740 \mathrm{rpm}$ with $80^{\circ}$ cutting angle produces a smoother surface that is $\left(\sum \mathrm{Ra}_{\mathrm{p}}\right)=5.76 \mu \mathrm{m}$ or in the roughness class $\mathrm{N9}$ while the spindle rotation speed is $440 \mathrm{rpm}$ with 80 potong cutting angle produces a surface coarse $\left(\sum \mathrm{Ra}_{\mathrm{p}}\right)=$ $11.47 \mu \mathrm{m}$ with $\mathrm{N10}$ surface roughness class.
\end{abstract}

Keywords : Spindle rotation speed, Cutting angle, Surface roughness

This is an open access article distributed under the Creative Commons 4.0 Attribution License

\section{Pendahuluan}

Dalam dunia industri, mesin-mesin perkakas sangat berperan dalam mendukung berhasilnya suatu proses produksi karena tiap bengkel mesin konstruksi dan bengkel-bengkel pengerjaan logam, pada umumnya mesin-mesin ini banyak digunakan dalam pembuatan atau perbaikan komponen tertentu dalam suatu mesin. Dari beberapa mesin perkakas yang ada salah satunya adalah mesin bubut. Mesin Bubut adalah suatu mesin perkakas yang digunakan untuk memotong benda yang diputar. Bubut sendiri merupakan suatu proses pemakanan benda kerja yang sayatannya dilakukan dengan cara memutar benda kerja kemudian dikenakan pada pahat yang digerakkan secara translasi sejajar dengan sumbu putar dari benda kerja. Gerakan putar dari benda kerja disebut gerak potong relatif dan gerakan translasi dari pahat disebut gerak umpan. 
Metrologi yang biasa disebut dengan ilmu pengukuran adalah disiplin ilmu yang mempelajari jenis-jenis alat ukur keteknikan, metode pengukuran, kalibrasi dan akurasi di bidang industri, ilmu pengetahuan dan teknologi. pada praktikum di labor atau workshop seperti: Pemesinan, Produksi pemesinan, Fabrikasi, Las Listrik, Pemograman CNC, dan Gambar Teknik. Mengingat pentingnya Metrologi Industri [1]

Salah satu karakteristik geometris yang ideal dari suatu komponen adalah permukaan yang halus [2]. Dalam prakteknya memang tidak mungkin untuk mendapatkan suatu komponen dengan permukaan yang betul-betul halus. Hal ini disebabkan oleh beberapa faktor, misalnya faktor manusia (operator) dan faktor-faktor dari mesinmesin yang digunakan untuk membuatnya. Akan tetapi, dengan kemajuan teknologi terus berusaha membuat peralatan yang mampu membentuk permukaan komponen degan tingkat kehalusan yang cukup tinggi menurut standar ukuran yang berlaku dalam metrologi yang dikemukakan oleh para ahli pengukuran geometris benda melalui pengalaman penelitian.

Tingkat kehalusan suatu permukaan memang peranan yang sangat penting dalam perencanaan suatu komponen mesin khususnya yang menyangkut masalah gesekan pelumasan, keausan, tahanan terhadap kelelahan dan sebagainya. Oleh karena itu, dalam perencanaan dan pembuatannya harus dipertimbangkan terlebih dulu mengenai peralatan mesin yang mana harus digunakan untuk membuatnya serta berapa ongkos yang harus dikeluarkan. Agar proses pembuatannya tidak terjadi penyimpangan yang berati maka karakteristik permukaan ini harus dapat dipahami oleh perencana lebih-lebih lagi oleh operator. Komunikasi karakteristik permukaan biasanya dilakukan dalam gambar teknik. Akan tetapi untuk menjelaskan secara sempurna mengenai karakteristik suatu permukaan nampaknya sulit.

Hasil pembubutan yang berkualitas tinggi dapat dilihat dari segi bentuk, kepresisian ukuran, dan karakteristik permukaan berupa kekasaran dari permukaan benda yang telah dibubut tersebut. Pada dasarnya setiap pengerjaan mesin mempunyai persyaratan kualitas permukaan (kekasaran permukaan) yang berbeda-beda, tergantung dari fungsinya. Karakteristik permukaan tersebut harus dapat digunakan sesuai dengan kebutuhan, sehingga efesiensi permukaan akan lebih sesuai dengan permukaannya. Kekasaran permukaan suatu komponen mesin selalu berhubungan dengan gesekan, pelumasan, tahan kelelahan, keausan, maupun perangkaian komponen-komponen mesin dan selalu berhubungan dengan suaian.

Kekasaran permukaan benda hasil pengerjaan pembubutan menjadi suatu tuntutan yang harus diperhatikan oleh setiap operator mesin bubut, karena kekasaran permukaan komponen mesin memiliki pengaruh dalam suatu rangkaian mesin seperti masalah keausan, tahanan terhadap kelelahan dan sebagainya. Tingkat kekasaran permukaan komponen mesin yang tinggi dapat menyebabkan terjadinya keausan yang cepat, sehingga komponen mesin cepat rusak dan akhirnya efesiensi kerja menjadi menurun dan tidak efesien waktu. Baja ST 37 merupakan golongan baja karbon rendah karena di dalam baja ST 37 terdapat kandungan karbon 0.17. Pengkodean ST 37 sendiri merupakan pengkodean untuk mempermudah dalam pemilihan baja [3].

Kekasaran permukaan produk hasil proses pembubutan memiliki fungsi yang sangat penting, maka setiap gambar kerja ada penunjukan syarat tentang kekasaran permukaan yang harus dipenuhi. Untuk mendapatkan kekasaran permukaan yang sesuai dengan yang diharapkan sehingga proses produksi mampu menghasilkan produk yang berkualitas dan diperlukan pengaturan faktorfaktor yang mempengaruhi tingkat kekasaran permukaan produk tersebut. Faktor-faktor yang mempengaruhi tingkat kekasaran permukaan benda logam dimesin bubut, antara lain: kecepatan spindel, gerak pemakanan (feeding), kedalaman pemakanan, kondisi mesin, bahan benda kerja, sudut pahat potong, material alat potong, pendinginan, kecepatan potong (cutting speed), dan operator.

Pahat bubut dan proses permesinan merupakan salah satu faktor penting yang menentukan keberhasilan proses permesinan. Geometri pahat terutama sudut-sudutnya harus dipilih dengan benar disesuaikan dengan jenis material benda kerja, material pahat, dan kondisi pemotongan, sehingga akan menurunkan temperatur pemotongan, serta didapatkan hasil yang mempunyai ketelitian dan kehalusan yang tinggi. Suatu proses pemesinan yang menggunakan pahat sebagai perkakas potongnya, harus memperhatikan geometri pahat tersebut karena geometri pahat merupakan salah satu faktor terpenting yang menentukan keberhasilan proses pemesinan [4], selain kecepatan potong ditentukan oleh diameter benda kerja faktor bahan benda kerja dan bahan pahat sangat menentukan harga kecepatan potong [5]. Dalam pemotongan (depth Of Cut) adalah jarak dari dasar pemotongan ke permukaan yang tidak dipotong dari benda kerja 
diukur tegak lurus" [6]. Untuk pahat bubut bermata potong tunggal, sudut pahat yang paling pokok adalah sudut beram (rake angle), sudut bebas (clearance angle), dan sudut sisi potong (cutting edge angle). Sudut potong merupakan sisi potong pahat yang menyentuh permukaan benda dan menyayat permukaan benda kerja. Akibat ketidak sempurnaan alat ukur, cara pengukuran dan cara evaluasi hasil pengukuran suatu permukaan benda kerja yang sesungguhnya (real, surface) tidak dapat dibuat grafiknya atau duplikatnya, melainkan hanya mendekati bentuk sesungguhnya [4].

Mekanika proses pemotongan logam membutuhkan parameter yang melibatkan kondisi pemotongan dan geometri serta kemampuan pahat potong. Semakin besar kecepatan potong semakin besar pula konsumsi tenaga mesinnya. Penampang serpihan dalam proses pemotongan besarnya tergantung kepada gerak makan (mm/put) atau dalam/tebalnya kedalaman potong $(\mathrm{mm})$. Dalam proses pemesinan, untuk mencapai kondisi pemotongan yang optimal dan stabil sangat perlu diperhatikan adanya kombinasi besaran laju pemotongan, gerak makan, dan kedalaman pemotongan yang sangat erat kaitannya terhadap umur pahat serta kualitas permukaan bahan termesin [7]. Pahat yang bergerak relatif terhadap benda kerja akan menghasilkan geram dan semetara itu permukaan benda kerja secara beratahap akan terbentuk menjadi komponen yang dikehendaki. Pahat dapat diklasifikasikan menjadi dua jenis, yaitu pahat bermata tunggal dan bermata jamak. Gerak relatif pahat terhadap benda kerja dapat dipisahkan menjadi dua komponen gerakan, yaitu gerak potong dan gerak makan. Menurut jenis kombinasi dari gerak potong dan gerak makan maka proses pemesinan dikelompokkan menjadi tujuh macam proses yang berlainan, yaitu: proses bubut, proses gurdi, proses freis, proses gerinda rata, proses gerinda silindris, proses sekrap, proses gergaji atau parut.

Sudut-sudut yang terdapat pada mata pahat disebut dengan sudut utama pahat (basic tool angle) dan komposisinya disebut juga sebagai geometri pahat (tool geometry). Susunan sudutsudut utama dan jari-jari mata potong (nose radius) disebut tanda pahat (tool signature). Menurut standarisasi dari ASA (American Standart Assosiation) tool signature dari single point tool meliputi: Rake angles, relief angles, cutting egde angles dan nose radius. Jika clereance angles dimasukkan dalam tool signature maka akan terlihat seperti gambar berikut. Akan tetap pada umumnya celreance angles tidak dimasukkan dalam tool signature karena dianggap sama dengan relief angles.

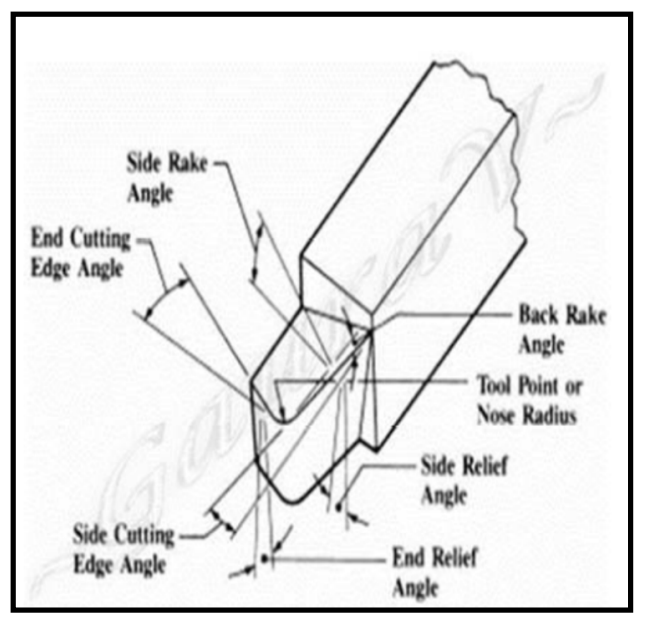

Gambar 1. Tanda pahat (tool signature) [7]

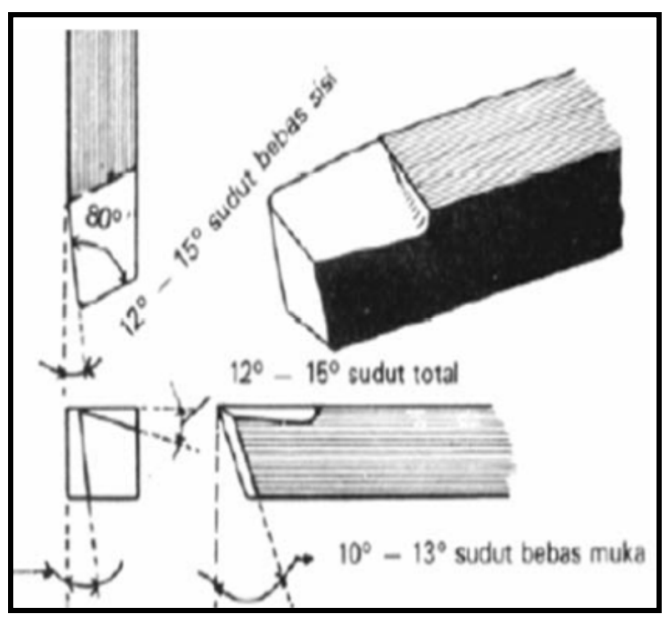

Gambar 2. Sudut pahat [7]

Keterangan gambar:

- Sudut garuk belakang (back rake angle) sudut antara face dan garis yang sejajar dengan base dan diukur pada bidang yang tegak lurus dengan mata potong sisi (side cutting edge)

- Sudut garuk sisi (side rake angle) sudut antara face dan garis yang sejajar dengan base dan diukur pada bidang yang tegak lurus pada base dan side cutting edge.

- Sudut mata potong ujung (end cutting edge angle) sudut antara ujung cutting edge dan garis tegak lurus pada shank.

- Sudut mata potong sisi (side cutting edge angle) sudut antara side cutting edge dan sisi lain dari shank.

- Sudut celah sisi (side relief angle) sudut kedua langsung dibawah side clearence angle. 
- Sudut celah ujung (end relief angle) sudut kedua langsung dibawah end clearence angle.

- Radius pojok (nose radius/tool point) merupakan perpotongan antara side cutting edge dengan end cutting edge.

Akibat ketidak sempurnaan alat ukur, cara pengukuran dan cara evaluasi hasil pengukuran suatu permukaan benda kerja yang sesungguhnya (real, surface) tidak dapat dibuat grafiknya atau duplikatnya, melainkan hanya mendekati bentuk sesungguhnya. Permukaan yang mendekati bentuk permukaan sesungguhnya disebut permukaan terukur (measure surface). Akibat penyimpanganpenyimpangan selama proses pemotongan, maka permukaan geometris ideal (geometrically ideal surface) yaitu permukaan yang dianggap mempunya bentuk yang sempurna, tidak mungkin dapat dibuat. Sedangkan permukaan yang disyaratkan pada gambar teknik dengan cara-cara standart tertentu disebut permukaan nominal (nominal surface).

Berdasarkan gambar teknik, dimana dinyatakan spesifikasi geometris suatu produk komponen mesin, salah satu atau beberapa jenis proses pemesinan harus dipilih sebagai suatu proses atau urutan yang digunakan untuk membuatnya. Bagi suatu tingkatan proses, ukuran obyektif ditentukan dan pahat harus membuang sebagian material benda kerja sampai ukuran obyektif tersebut dicapai. Hal ini dapat dilaksanakan dengan cara menentukan penampang geram (sebelum terpotong) dan selain itu setelah berbagai aspek teknologi ditinjau, kecepatan pembuangan geram dapat dipilih supaya waktu pemotongan sesuai dengan yang dikehendaki. Situasi seperti ini timbul pada setiap perencanaan proses pemesinan. Beberapa elemen dasar pemesinan yang harus diketahui: a. kecepatan potong (cutting speed): $\mathrm{V}$ $(\mathrm{m} / \mathrm{min})$,

b. kecepatan makan (feeding speed): vf $(\mathrm{mm} / \mathrm{min}) \quad$ c. kedalaman potong (depth of cut): a (mm), d. waktu pemotongan (cutting time): tc (min), e. kecepatan penghasil geram: Z ( $\mathrm{cm} 3 / \mathrm{min})$, elemen proses pemesinan tersebut $(\mathrm{V}, \mathrm{vf}, \mathrm{a}, \mathrm{tc}, \mathrm{Z})$ dihitung berdasarkan dimensi benda kerja dan pahat serta besaran dari mesin perkakas [6]. Besaran mesin perkakas yang dapat diatur bermacam-macam tergantung dari jenis mesin perkakas. Oleh sebab itu, rumus yang dipakai untung menghitung setiap elemen proses pemesinan dapat berlainan.

Profil adalah garis yang dihasilkan pada proses pemotongan, khususnya pemotongan orthogonal dan pemotongan miring (oblique). Beberapa istilah profil dan parameter permukaan dapat dilihat pada gambar dibawah ini:

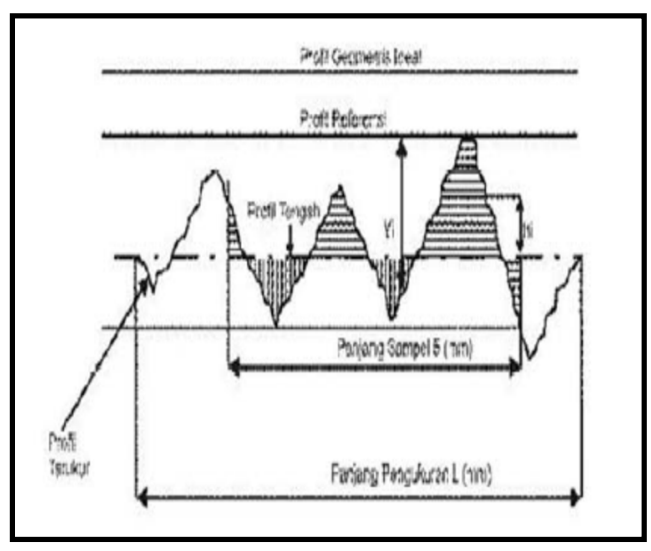

Gambar 3. Macam profil dan parameter Permukaan [7]

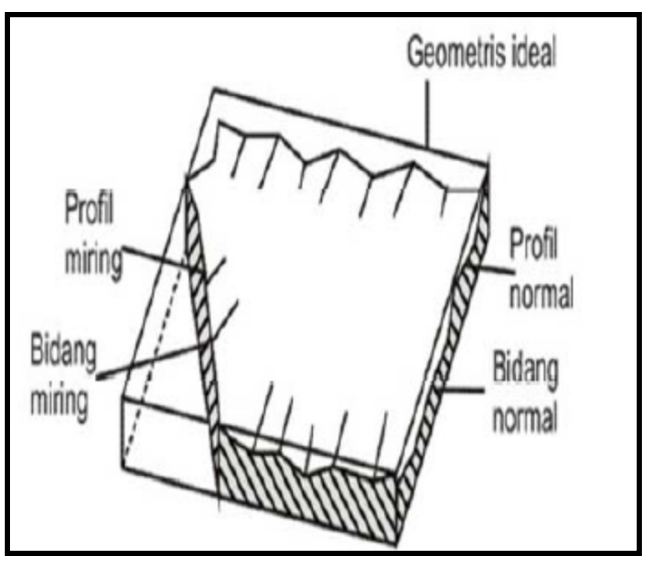

Gambar 4. Bidang dan profil penampang Permukaan [7]

Keterangan gambar:

- Profil geometri ideal (geometrically ideal profile), adalah profil permukaan geomteris ideal (dapat berupa garis lurus ataupun garis lengkung).

- Profil terukur (measured profile), adalah profil dari permukaan terukur.

- Profil referensi (reference profile), adalah profil yang digunakan sebagai referensi untuk menganalisa ketidakteraturan konfigurasi permukaan. Profil ini dapat berupa garis lurus atau garis bentuk sesuai dengan profil geometris ideal, serta menyinggung puncak tertinggi dari profil terukur dalam suatu panjang sampel.

- Profil dasar (root profile), adalah profil referensi yang digeserkan ke bawah (arah tegak lurus terhadap profil geometris ideal pada suatu panjang sampel), sehingga menyinggung titik 
terendah dari profil terukur.

- Profil tengah (centre profile), adalah profile reference yang digeser ke bawah sedemikian rupa, sehingga sejumlah luas dari daerah-daerah diatas profil tengah sampai ke profil terukur adalah sama dengan jumlah luas dari daerah dibawah profil tengah sampai ke profil terukur.

- Kedalaman total (peak to valley height, Rt), jarak rata-rata antara profil referensi dan profil dasar $(\mu \mathrm{m})$.

- Kedalaman perataan (peak to mean line, $R p$ ), jarak rata-rata antara profil referensi dengan profil terukur.

$$
\mathrm{Rp}=1 / 1 \int_{0}^{1} \text { yid. }(\mu m)
$$

- Kekasaran rata-rata aritmetis (mean roughness index, $R a$ ), adalah harga rata-rata aritmetis dari harga absolutnya jarak antara profil terukur dengan profil tengah.

$$
\mathrm{Ra}=1 / 1 \int_{0}^{1} \text { hid. }(\mu m)
$$

Fakta yang sering terjadi dilapangan dalam pengamatan penulis, kecepatan putaran spindel dan sudut potong pahat dan besar sudutnya kurang diperhatikan, biasanya seorang operator mesin yang penulis temukan hanya menggunakan perasaannya (feeling) saja, sehingga banyak benda kerja yang dihasilkan menjadi kasar permukaannya. Untuk meminimalisir kekasaran permukaan tersebut banyak dari operator menggunakan amplas atau kikir untuk menghaluskan permukaan benda tersebut.

\section{Metode Penelitian}

Penelitian ini merupakan penelitian eksperimen. Metode penelitian eksperimen dapat diartikan sebagai metode penelitian yang digunakan untuk mencari pengaruh perlakuan terhadap yang lain dalam kondisi yang terkendalikan [8]. Penelitian ini untuk melihat tingkat kekasaran permukaan mild steel ST 37 hasil pembubutan dengan menggunakan pahat bubut HSS (High Speed Steel) dengan kecepatan putaran spindel dan sudut potong pahat yang berviariasi dan mencari pengaruh kecepatan potong spindel dan sudut potong pahat terhadap kekasaran permukaan logam hasil pembubutan material mild steel ST 37. Untuk mengukur kekasaran permukaan benda menggunakan Surface Tester
Mitutoyo SJ-201P, dimana hasil pengujian diperoleh melalui percobaan langsung terhadap benda uji. Berdasarkan pokok permasalahan yang telah dibahas pada bab sebelumnya, data yang diperoleh melalui hasil uji kekasaran permukaan benda uji.

Objek yang digunakan pada penelitian ini yaitu Mild Steel ST 37 dengan diameter 25,4 mm dengan panjang $70 \mathrm{~mm}$. jumlah specimen uji ada 9 buah dan direplika sebanyak 3 kali, maka ada 27 data penelitian dengan menggunakan pahat bubut HSS. Pada penelitian ini menggunakan pahat jenis HSS (High Speed Steel), bahan baja Mild Steel 37 dengan diameter $25,4 \mathrm{~mm}$ yang akan dibubut menjadi $20 \mathrm{~mm}$ sepanjang $40 \mathrm{~mm}$.

Berdasarkan landasan teori yang ada, harga cutting speed untuk baja ST 37 adalah 30-42 m/menit. Harga kecepatan potong (cutting speed) yang penulis ambil sebagai berikut : $35 \mathrm{~m} /$ menit. Maka diameter rata-rata benda adalah sebagai berikut :

$D=\frac{D 0+D m}{2}=\frac{25+20}{2}=22.5 \mathrm{~mm}$

Sehingga kecepatan putaran mesin adalah :

$n=\frac{\operatorname{Cs} \times 1000}{\pi \times D}=\frac{35 \times 1000}{3.14 \times 22,5}=\frac{35000}{70,65}=495,39 \mathrm{Rpm}$

Instrumen penelitian adalah alat atau fasilitas yang digunakan oleh peneliti dalam mengumpulkan data agar pekerjaannya lebih mudah dan hasilnya lebih baik, dalam arti lebih cermat, lengkap dan sistematis sehingga lebih mudah diolah [9]. Instrumen pengumpulan data pada penelitian dilakukan dengan langkah-langkah sebagai berikut : menyiapkan tabel-tabel yang dibutuhkan sesuai dengan penelitian yang dilakukan, Mengisi tabel yang sudah disiapkan tersebut dengan data hasil penelitian dan Analisis pengujian benda kerja.

\section{HASIl dan PeMbahasan}

\section{A. Hasil}

Berdasarkan data hasil pengukuran kekasaran permukaan menggunakan alat ukur surface tester mitutoyo SJ-201P pada spesimen Mild Steel ST 37 dari hasil pengerjaan proses bubut kering tanpa menggunakan pendingin menggunakan alat potong HSS (High Speed Steel) merk bohler yang divariasikan dengan kecepatan putaran spindel dan sudut potong pahat maka diperoleh data hasil pengukuran sebagaimana tertera pada Tabel 1 . 
Tabel 1. Data Hasil Penelitian

\begin{tabular}{|c|c|c|c|c|c|c|c|c|c|}
\hline \multirow[b]{2}{*}{$\begin{array}{c}\text { Kecepatan } \\
\text { Putaran } \\
\text { (Rpm) }\end{array}$} & \multirow{2}{*}{$\begin{array}{l}\text { Sudut } \\
\text { Potong }\end{array}$} & \multirow{2}{*}{$\begin{array}{l}\text { Benda } \\
\text { Uji }\end{array}$} & \multirow[b]{2}{*}{$\begin{array}{c}\text { Kedalaman } \\
\text { Pemakanan } \\
\text { (mm) }\end{array}$} & \multicolumn{5}{|c|}{ Tingkat Kekasaran $(\mu \mathrm{m})$} & \multirow[b]{2}{*}{$\begin{array}{c}\text { Kekasaran } \\
\text { Permukaar } \\
\Sigma \mathrm{Ra},\end{array}$} \\
\hline & & & & A & B & $\mathrm{C}$ & $\mathrm{D}$ & $\Sigma$ Ras & \\
\hline \multirow[t]{12}{*}{440} & \multirow[t]{4}{*}{$80^{\circ}$} & 1 & 0,50 & 12,75 & 12,97 & 13,07 & 12,73 & 12,88 & \\
\hline & & 2 & 0,50 & 11,36 & 11,78 & 12,09 & 11,58 & 11,70 & \\
\hline & & 3 & 0,50 & 9,65 & 9,55 & 9,72 & 10,46 & 9,84 & \\
\hline & & \multicolumn{6}{|c|}{$\Sigma$ Rap } & 11,47 & $\mathrm{~N} 10$ \\
\hline & \multirow[t]{4}{*}{$85^{\circ}$} & 1 & 0,50 & 10,54 & 11,56 & 11,56 & 11,54 & 11,3 & \\
\hline & & 2 & 0,50 & 9,21 & 8,74 & 8,46 & 8,42 & 8,70 & \\
\hline & & 3 & 0,50 & 8,00 & 8,44 & 8,14 & 9,47 & 8,51 & \\
\hline & & \multicolumn{6}{|c|}{$\Sigma$ Rap } & 9,50 & $\mathrm{~N} 10$ \\
\hline & \multirow[t]{4}{*}{$90^{\circ}$} & 1 & 0,50 & 9,23 & 8,85 & 8,14 & 9,51 & 8,93 & \\
\hline & & 2 & 0,50 & 8,77 & 9,20 & 8,59 & 7,21 & 8,44 & \\
\hline & & 3 & 0,50 & 7,96 & 7,53 & 7,84 & 8,54 & 7,96 & \\
\hline & & \multicolumn{6}{|c|}{$\Sigma$ Rap } & 8,44 & N10 \\
\hline \multirow[t]{12}{*}{540} & \multirow[t]{4}{*}{$80^{\circ}$} & 1 & 0,50 & 11,72 & 9,05 & 11,59 & 9,09 & 10,36 & \\
\hline & & 2 & 0,50 & 8,83 & 9,98 & 9,07 & 9,38 & 9,31 & \\
\hline & & 3 & 0,50 & 8,90 & 8,40 & 6,70 & 7,00 & 7,75 & \\
\hline & & \multicolumn{6}{|c|}{$\Sigma$ Rap } & 9,14 & N10 \\
\hline & \multirow[t]{4}{*}{$85^{\circ}$} & 1 & 0,50 & 10,01 & 9,78 & 10,40 & 9,19 & 9,84 & \\
\hline & & 2 & 0,50 & 10,11 & 9,19 & 10,01 & 9,56 & 9,71 & \\
\hline & & 3 & 0,50 & 8,27 & 8,93 & 7,24 & 6,98 & 7,85 & \\
\hline & & \multicolumn{5}{|c|}{ ¿Rap } & & 9,13 & N10 \\
\hline & \multirow[t]{4}{*}{$90^{\circ}$} & 1 & 0,50 & 7,23 & 7,57 & 8,37 & 8,83 & 8 & \\
\hline & & 2 & 0,50 & 7,02 & 7,71 & 7,33 & 7,24 & 7,32 & \\
\hline & & 3 & 0,50 & 7,84 & 6,32 & 7,07 & 7,51 & 7,18 & \\
\hline & & \multicolumn{5}{|c|}{$\Sigma$ Rap } & & 7,50 & N10 \\
\hline \multirow[t]{12}{*}{740} & \multirow[t]{4}{*}{$80^{\circ}$} & 1 & 0,50 & 7,63 & 7,04 & 6,26 & 7,34 & 7,06 & \\
\hline & & 2 & 0,50 & 5,89 & 6,05 & 5,46 & 5,96 & 5,84 & \\
\hline & & 3 & 0,50 & 5,08 & 3,99 & 4,42 & 4,06 & 4,38 & \\
\hline & & \multicolumn{6}{|c|}{$\Sigma$ Rap } & 5,76 & N9 \\
\hline & \multirow[t]{4}{*}{$85^{\circ}$} & 1 & 0,50 & 10,58 & 11,53 & 11,78 & 11,47 & 11,34 & \\
\hline & & 2 & 0,50 & 9,56 & 9,72 & 9,43 & 10,06 & 9,69 & \\
\hline & & 3 & 0,50 & 7,77 & 7,81 & 7,71 & 7,81 & 7,77 & \\
\hline & & \multicolumn{6}{|c|}{$\Sigma$ Rap } & 9,6 & $\mathrm{~N} 10$ \\
\hline & $90^{\circ}$ & 1 & 0,50 & 9,48 & 9,72 & 9,38 & 9,95 & 9,63 & \\
\hline & & 2 & 0,50 & 9,46 & 9,78 & 9,90 & 9,23 & 9,59 & \\
\hline & & 3 & 0,50 & 9,38 & 9,93 & 9,11 & 9,56 & 9,49 & \\
\hline & & & & & & & & 9,57 & N10 \\
\hline
\end{tabular}

Hasil pengukuran kekasaran permukaan pada 27 spesimen hasil dari proses pembubutan kering tidak menggunakan pendingin dengan kecepatan putaran spindel $(\mathrm{n})=440,540,740 \mathrm{Rpm}$ dan sudut potong pahat $80^{\circ}, 85^{\circ}$, dan $90^{\circ}$. Angka kekasaran permukaan terkecil yang dicapai adalah $\left(\Sigma \mathrm{Ra}_{\mathrm{p}}\right)=$ $5,76 \mu \mathrm{m}$ dengan kelas kekasaran permukaan $\mathrm{N} 7$ yaitu pada parameter kecepatan putaran $740 \mathrm{Rpm}$ dengan sudut potong $80^{\circ}$. Sedangkan angka 
kekasaran permukaan yang terbesar yang dicapai adalah $\left(\Sigma \mathrm{Ra}_{\mathrm{p}}\right)=11,47 \mathrm{C}$ dengan kelas kekasaran permukaan N10 yaitu pada parameter kecepatan $440 \mathrm{Rpm}$ dengan sudut potong pahat $80^{\circ}$. Nilai tingkat kekasaran yang dicapai adalah antara N9 N10 (ISO roughness number).

Terjadinya perbedaan nilai kekasaran dari ketiga spesimen dalam satu sudut potong pahat, ini dikarenakan yang pertama tidak meratanya komposisi benda kerja, yang kedua dalam proses pembubutan tidak menggunakan cairan pendingin pada saat pembubutan berlangsung sehingga pahat cepat panas dan mudah tumpul, yang ketiga dalam pengasahan sudut potong pahat tidak tepat dan tidak presisi dikarenakan dalam proses pengasahan pahat masih menggunakan cara manual.

\section{B. Pengaruh Sudut Potong dan Kecepatan} Putaran Spindel terhadap Kekasaran Permukaan Pada Proses Bubut Mild Steel ST 37.

Didapat data dan dihitung nilai rata-rata kekasaran permukaan per spesimen dan rata-rata kekasaran permukaan berdasarkan sudut potong pahat dapat dilihat Gambar 5 .

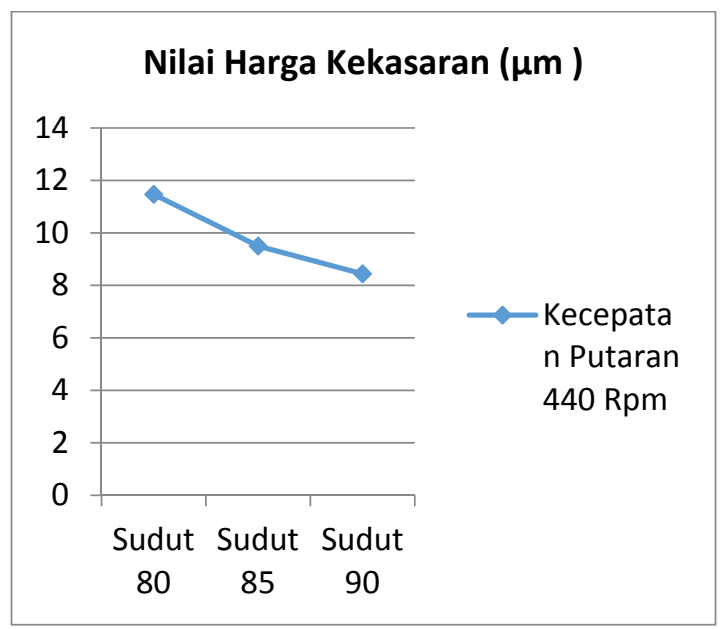

Gambar 5. Grafik Kekasaran Kecepatan Putaran Spindel 440 Rpm

Sudut potong $80^{\circ}$ lebih tinggi nilai kekasaran permukaannya yaitu $\left(\Sigma \mathrm{Ra}_{\mathrm{p}}\right)=11,47 \mu \mathrm{m}$, ini dikarenakan sudut potong pahat agak runcing dengan kecepatan putaran rendah sehingga kekasaran permukaan yang dihasilkan kasar, dan juga faktor komposisi benda yang tidak merata dapat mempengaruhi ingkat kekasaran dan juga dalam pengasahan alat potong menggunakan cara manual dapat dilihat pada Gambar 6 .

Sudut potong $80^{\circ}$ lebih tinggi nilai kekasaran permukaannya yaitu $\left(\Sigma \mathrm{Ra}_{\mathrm{p}}\right)=9,14 \mu \mathrm{m}$, ini dikarenakan kecepatan putaran rendah sehingga kekasaran permukaan yang dihasilkan kasar, dan juga faktor komposisi benda yang tidak merata dapat mempengaruhi ingkat kekasaran dan juga dalam pengasahan alat potong menggunakan cara manual dapat dilihat Gambar 7.

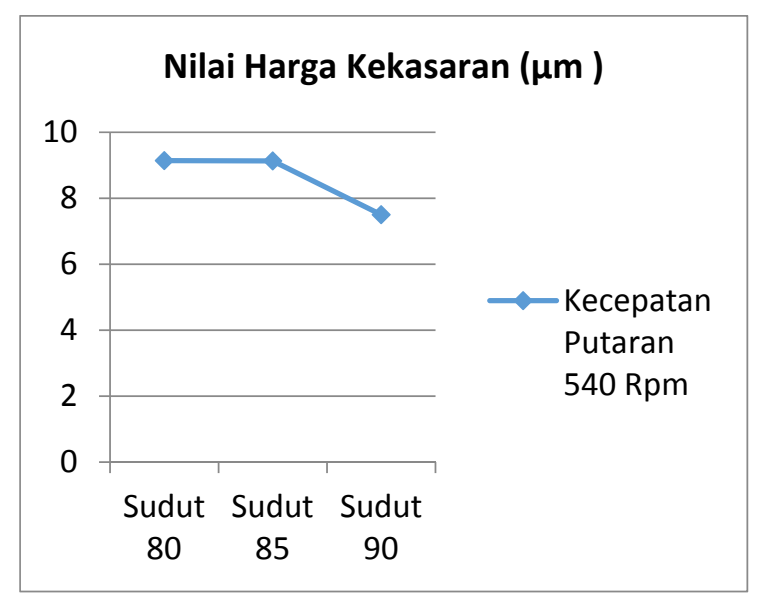

Gambar 6. Grafik Kekasaran Kecepatan Putaran Spindel 540 Rpm

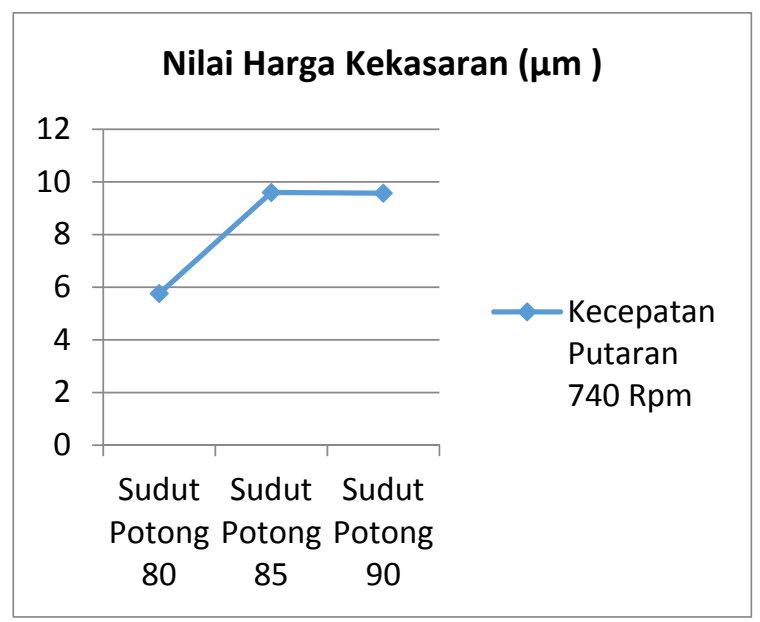

Gambar 7. Grafik Kekasaran Kecepatan Putaran Spindel 740 Rpm

Sudut potong $85^{\circ}$ lebih tinggi nilai kekasaran permukaannya yaitu $\left(\Sigma \mathrm{Ra}_{\mathrm{p}}\right)=9,60 \mu \mathrm{m}$, kekasaran permukaan yang dihasilkan kasar, dan juga faktor komposisi benda yang tidak merata dapat mempengaruhi ingkat kekasaran dan juga dalam pengasahan alat potong menggunakan cara manual.

Pada percobaan dengan kecepatan putaran spindel $440 \mathrm{Rpm}$ dengan sudut potong pahat sebesar $80^{\circ}$ dengan tingkat kekasaran permukaan paling tinggi diantara percobaan lainnya, dengan nilai kekasaran permukaan $\left(\Sigma \mathrm{Ra}_{\mathrm{p}}\right)=11,47 \mu \mathrm{m}$ dapat dilihat Gambar 8 


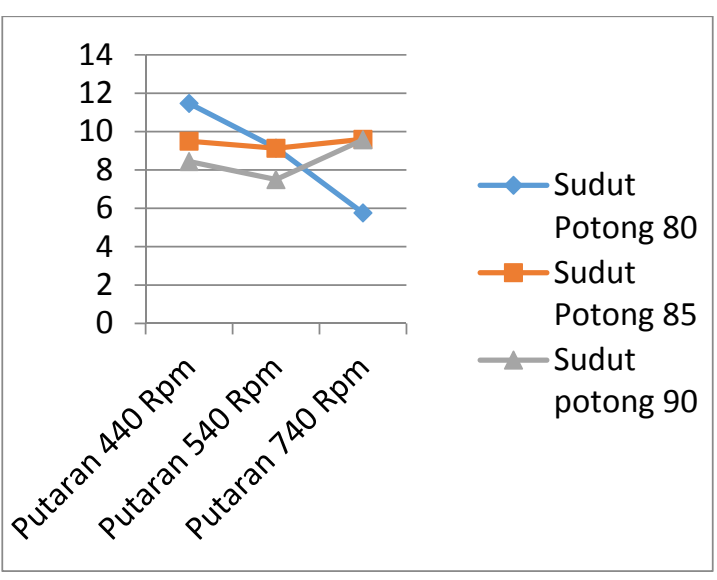

Gambar 8. Grafik kekasaran Kecepatan Kekasaran Putaran Spindel dan sudut Potong Pahat

Pemakaian sudut potong $80^{\circ}$ dengan putaran rendah menghasilkan nilai kekasaran permukaan yang tinggi. Ini dikarenakan putaran rendah.

\section{KESIMPULAN}

Proses bubut permukaan ini, nilai $\Sigma \mathrm{Ra} \mathrm{a}_{\mathrm{p}}$ harga kekasaran permukaan yang halus atau yang terbaik didapat pada sudut potong $80^{\circ}$ dan kecepatan 740 Rpm dengan $\left(\Sigma \mathrm{Ra}_{\mathrm{p}}\right)=5,76 \mu \mathrm{m}$ atau pada kelas kekasaran $\mathrm{N} 9$ sedangakan nilai $\Sigma \mathrm{Ra}_{\mathrm{p}}$ harga kekasaran permukaan yang kasar didapat pada sudut potong $80^{\circ}$ dan kecepatan putaran spindel $440 \mathrm{Rpm}\left(\Sigma \mathrm{Ra}_{\mathrm{p}}\right)=11,47 \mu \mathrm{m}$ atau pada kelas kekasaran N10.

\section{DAfTAR PUSTAKa}

[1] Indrawan, E., \& Rifelino, R. (2014). PENINGKATAN AKTIFITAS BELAJAR MAHASISWA MELALUI PENGGUNAAN MULTIMEDIA DALAM MATA KULIAH METROLOGI INDUSTRI. Penelitian Pendidikan, 5(1).

[2] Munaji, Sudji, 1980, Dasar-Dasar Metrologi Industri, proyek Pengembangan Lembaga Pendidikan Tenaga Kependidikan, Jakarta.

[3] Bondan T. Sofyan. (2010). Pengantar Material Teknik. Jakarta: Salemba Teknika.

[4] Paridawati. (2015). Pengaruh Kecepatan dan Sudut Potong Terhadap Kekasaran Benda Kerja Pada Mesin Bubut. Bekasi: Universitas Islam 45 Bekasi.

[5] Widarto. (2008). Teknik Pemesinan. Jakarta: Direktorat Pembinaan Sekolah Menengah Kejuruan
[6] A Yufrizal. (1993). Teknologi Proses Pemesinan Dasar-Dasar Pengetahuan Mesin Bubut. Padang: FPTK IKIP Padang.

[7] Rochim, Taufiq, 1985, Teori dan Teknologi Proses Pemesinan, Higher Education Development Support, Jakarta

[8] Suharsimi Arikunto. (2010). Prosedur Penelitian: Suatu Pendekatan Praktik. Jakarta: Rineka Cipta.

[9] . (2013). Prosedur Penelitian Suatu Pendekatan Praktek. Jakarta: Rineka Cipta

\section{Biodata Penulis}

Yufrizal A, lahir di Padang, 21 April 1961. Sarjana Pendidikan di Jurusan Teknik Mesin FPTK 1981-1985. Tahun 2012 memperoleh gelar Magister Pendidikan di jurusan Teknologi Pendidikan Program Pascasarjana UNP dengan bidang konsentrasi Pendidikan Kejuruan. Staf pengajar di jurusan Teknik Mesin FT UNP sejak tahun 1986- sekarang.

Eko Indrawan, lahir di Pulau Kijang, 14 Januari 1980. Sarjana di Jurusan Teknik Mesin ITP Padang Tahun 1999-2003. Tahun 2008 memperoleh gelar Magister Pendidikan di jurusan Teknologi Pendidikan Program Pascasarjana UNP dengan bidang konsentrasi Pendidikan Kejuruan. Staf pengajar di jurusan Teknik Mesin FT UNP sejak tahun 2010- sekarang.

Nofri Helmi, lahir di Batu Sangkar, 04 November 1963. Sarjana Pendidikan di Jurusan Teknik Mesin FPTK 1983-1987. Tahun 1998 memperoleh gelar Magister di Program Pascasarjana Unair Surabaya dengan bidang Keselamatan Kerja. Staf pengajar di jurusan Teknik Mesin FT UNP sejak tahun 1989sekarang.

Abdul Aziz, lahir di Kodya Padang, 04 Maret 1962. Sarjana Pendidikan di Jurusan Teknik Mesin FPTK 1981-1985. Tahun 2010 memperoleh gelar Magister Pendidikan di jurusan Teknologi Pendidikan Program Pascasarjana UNP dengan bidang konsentrasi Pendidikan Kejuruan. Staf pengajar di jurusan Teknik Mesin FT UNP sejak tahun 1986- sekarang.

Yoga Amanda Putra, Sarjana Pendidikan di Jurusan Teknik Mesin FT 2014-2018 